\title{
STUDI PEMURNIAN GAMBIR (Uncaria gambir Roxb) DENGAN MENGGUNAKAN ARANG AKTIF DARI TEMPURUNG KELAPA SAWIT SEBAGAI ADSORBEN
}

\author{
Norman Ferdinal ${ }^{1}$, Novizar Nazir ${ }^{2}$ \\ ${ }^{1}$ Laboratorium Kimia Organik Sintesis Jurusan Kimia Universitas Andalas Padang, \\ ${ }^{2}$ Fakultas Teknologi Pertanian Universitas Andalas Padang.
}

\begin{abstract}
The purpose of this research is to know the effect of particle size and concentration activator $\mathrm{MgCl}_{2}$ to effectiveness the active carbon and examine the ability of the best active carbon that produced as adsorben to purifying gambier. This research is done in 3 steps: (A) the making of the active carbon from variety of size : $\geq 250 \mu \mathrm{m}(\mathrm{A} 1), 180 \mu \mathrm{m}<\mathrm{F} \leq 250 \mu \mathrm{m}$ (A2), $125 \mu \mathrm{m}<\mathrm{F} \leq 80 \mu \mathrm{m}$ (A3) and $\mathrm{F} \leq$ 125 (A4) and some the activator concentration $\mathrm{MgCl}_{2}: 0 \%$ (B1), 20\% (B2), 40\% (B3), 60\% (B4) and $80 \%$ (B5), (B) the testing quality of the active carbon include the content of water and adsorbable Iod and $(\mathrm{C})$ the testing of active carbon as adsorben to purifying of gambier. To examine about the quality of active carbon got the best active carbon from carbon of coconut shell of sawit by size $\leq 125 \mu \mathrm{m}$ with activator concentration $20 \% \mathrm{MgCl}_{2}$ with the content of water $2.23 \%$ and adsorbable Iod $3080.97(\mathrm{mg} / \mathrm{g})$. The gambir rendemen the best purifying that produced is $55.5 \%$ by the content of dust $1.303 \%$ and the content of catechin $72.40 \%$.
\end{abstract}

Keywords: Catechin compounds, Active carbon.

\section{DAFTAR PUSTAKA}

1. Linkenheil, Klaus, The Gambir Processing Industry in West Sumatera, ATIAMI dan Departemen Perindustrian dan Perdagangan Sumatera Barat, 1998.

2. K. Jankowska, S. Andrzes, and C. Jerzy, Active Carbon, Ed. I, Ellis Hardwood, New York, 1991.

3. F.F. Baker, C.E. Miller, A.J. Repik dan E. D. Tollen, Activated Carbon, Dalam Encyclopedia of Separation Technology, Volume I, John Wiley and Sons, New York, 1997.

4. Asfaruddin, S. Siswarjono, G. Rahmi, Pengaruh Konsentrasi Aktivator Magnesium Klorida dalam Pembuatan Karbon Aktif dari Tandan Kosong Sawit Untuk Pemucatan Minyak Sawit, $J$. Teknologi Pertanian Andalas, 06(10), (2001).
5. G. Pari, Kualitas Arang Aktif dari 5 Jenis Kayu, Bulletin Penelitian Hasil Hutan, 14(2), 1996.

6. H. Mukhtar, Telmologi Pemumian Gambir, Makalah pada Seminar Nasional Hasil-Hasil Penelitian dan Pengkajian Pertanian, BPTP Sukarami dan Peragi, Padang, 21-22 Maret 2000.

7. Standar Nasional Indonesia, (SNI) 063730-1995, Penentuan Kadar Air.

8. Standar Nasional Indonesia, (SNI) 063730-1995, Daya Serap terhadap $I_{2}$ (mg/g).

9. Standar Nasional Indonesia, (SNI O13391-1994, Revisi 1999), Rendemen.

10. Standar Nasional Indonesia, (SNI O13391-1994, Revisi 1999), Kadar Catechin.

11. H. Setyaningsih, Pengolahan Limbah dengan Proses kimia dan Adsorpsi Karbon Aktif, Tesis Program Pascasarjana UI, Jakarta, 1995. 